\title{
Human Resource Management (HRM) Practices of the Electricity Sector in Bangladesh
}

\author{
Md. Shafiqul Islam* \\ Dept. of Accounting \& Information Systems, Jatiya Kabi Kazi Nazrul Islam University, Bangladesh and Ph.D. \\ Fellow, Zhongnan University of Economics and Law, Wuhan, China.
}

\begin{abstract}
*Corresponding Authors: Md. Shafiqul Islam, Dept. of Accounting \& Information Systems, Jatiya Kabi Kazi Nazrul Islam University, Bangladesh and Ph.D. Fellow, Zhongnan University of Economics and Law, Wuhan, China.
\end{abstract}

\begin{abstract}
The main purpose of the study is to examine the Human Resource Management practices of the Electricity Sector in Bangladesh considering the recruitment, training, and promotion practices. The another objective is to explore the challenges in training practices facing and to give some suggessions of improving H.R. practices. The Study uses a descriptive survey research design. From the target population, the study selected a sample of 30, and collected data through questionnaire. For data analysis, the research has been conducted using qualitative methods. The study has found out that there is a standard H.R. practice existing in the electricity sector. An improved H.R. management is practiced in the Electricity sector; some lack in the promotion and payment process that should be solved to achieve the organization's ultimate goal. the mean of agree is about 5 times higher than not agree, so it is clear that the respondents are satisfied with HR management service. There is a minor limitations of the research that the number of respondents as a sample could be incresased a much more reliable findings could be reached. The study is hoped to be practically useful to Electricity sector by making the management understand the importance of implementing Human Resource Management Systems. It is original survey data based research, and it is reliable in practical sense of implimentation as my konwledge. This study is original with respect to the specific sector with few studies focused previously.
\end{abstract}

Keywords: HRM, Efficiency, H.R. Policies, training, Electricity etc.

JEL Classification: $003, M 5$

\section{INTRODUCTION}

The utility electricity sector in Bangladesh has one national grid with an installed capacity of 21,419 MW as of September 2019. The total installed capacity is 20,000 MW (combining solar power). Bangladesh's energy sector is booming. Recently Bangladesh started construction of the 2.4-gigawatt (GW) Rooppur Nuclear Power Plant expected to go into operation in 2023. According to the Bangladesh Power Development Board in July 2018, 90 percent of the population had access to electricity. However per capita energy consumption in Bangladesh is considered low.

Electricity is the major source of power for most of the country's economic activities. Bangladesh's total installed electricity generation capacity (including captive power) was 15,351 megawatts (MW) as of January 2017 and 20,000 megawatts in 2018. The largest energy consumers in Bangladesh are industries and the residential sector, followed by the commercial and agricultural sectors.

As of $2015,92 \%$ of the urban population and $67 \%$ of the rural population had access to electricity. An average of $77.9 \%$ of the population had access to electricity in Bangladesh. Bangladesh will need an estimated 34,000 MW of power by 2030 to sustain its economic growth of over 7 percent. Problems in Bangladesh's electric power sector include high system losses, delays in completion of new plants, low plant efficiency, erratic power supply, electricity theft, blackouts, and shortages of funds for power plant maintenance. Overall, the country's generation plants have been unable to meet system demand over the past decade.

On 2 November 2014, electricity was restored after a day-long nationwide blackout. A transmission line from India had failed, which "led to a cascade of failures throughout the national power grid," and criticism of "old grid infrastructure and poor management." However, in a recent root-cause analysis 
report the investigating team has clarified that the fault was actually due to lack of coordination and poor health of transmission and distribution infrastructure that caused the blackout.

Bangladesh's energy infrastructure is relatively small, insufficient, and poorly managed. The per capita energy consumption in Bangladesh is one of the lowest (321 kWH) worldwide. Noncommercial energy sources, such as wood fuel, animal waste, and crop residues, are estimated to account for over half of their energy consumption. In Bangladesh's electric power sector, problems include corruption in the administration, high system losses, poor HRM practice and delays in completion of new plants, low plant efficiencies, erratic power supply, electricity theft, blackouts, and shortages of funds for power plant maintenance. Overall, the country's generation plants have been unable to meet system demand over the past decade.

\subsection{The Objective of the Study}

The objectives of the Study are:

- To examine the Human Resource Management practices of the Electricity Sector in Bangladesh.

- To findout the recruitment, training practices in the Electricity Sector.

- To know the critical Issues with the current training regime

- To give some recommendations of improving H.R. practices in the Electricity Sector.

\subsection{Limitations of the Study}

In carrying out this Study, the researcher came across some difficulties, like sample respondents are not so large. It should be conducted more sampling. At the time of carrying out the research, most of the respondents were carrying out their routine jobs, and as a result, finding time to fill in the questionnaires is difficult. It called for constant communication between the researcher and the institutions to find the right fit in terms of time, allowing for collecting data from all the respondents.

\section{REVIEW OF LITERATURE}

Employees play a significant role in getting the competitive advantage in service-oriented organizations (Brill and Konar, 2004). Besides, a commitment performance approach views employees as resources or assets and values their voice. Employee performance is the tool of measurement of organizational performance. Employee performance is originally what an employee does or does not do. Employees' performance could include a quantity of output, quality of output, timeliness of production, presence at work, and cooperativeness (Rousseau, 2004). Human Resources are the biggest and most valuable asset and tools of overall development, efficiency, and effectiveness in any organization irrespective of the companies' sizes.

Good and proper usage of these resources leads to the organization's technological, economic, and ecological development. The present global corporate governance scenario assigns the highest level of significance to the organization's human resources or human capital.A study of human resource management practices in 249 U.S. affiliates of foreign-based multinational corporations (MNCs) shows that in general affiliate HRM practices closely follow local practices, with differences among specific practices. (Philip M. Rosenzweig \& Nitin Nohria, 1994). The nature and needs of the local labor market are stronger predictors of the transfer of HR practices than those factors identified in extant international human resource management frameworks, such as institutional and cultural distance, Mohan Pyari Maharjan \& Tomoki Sekiguchi ,2016. The contingency perspective on human resource management (HRM) advocates that HRM practices fit the internal or external situation of the organization. The results show two sets of HRM practices relating to the major organizational changes in the five companies, that is, reorganization and downsizing, (Sabine Raeder,2019.) The findings of the study showed significant effects of GHRM practices, i.e. (training and development, performance appraisal, and reward and compensation), on Organizational Sustainability,( Fiza Amjad, et.,al, 2021)

Akio Morita, the founder of Sony Corporation, the leading electronics giant of the world, once remarked, "There is no 'magic' in Japanese companies' success in general and Sony in particular. The secret of their success is simply the way they treat their employees. (Akio Morita, 1986) Not only the 'Japanese companies but the companies worldwide have realized the importance of human resource practices, popularly known as HRM. Human resource practices are found in every organization, but their significance lies in their proper use and management. Now China is the fastest growing economy 
in the world. However, it is the most populous nation in the world. The primary reason for Chinese dominance in global business is the large investment made in human resources and their management. (J. Phillip, 1998.)

The design of the human resources information systems supports in assessing the value of the human resources fiscally and contributes to planning these resources on the economic unit, as well as the national one through the contribution in drawing the labor and employment policies and the other supported policies like migration, payments, promotions, and motives in a scientific way (Dessler, 2005).

Human resource management is the new enhanced version of the traditional term 'personnel' management. The conventional dictum of personnel administration or management was more concerned with the enforcement of rules and regulations. It was affected by more hierarchy, less effectiveness, orthodox attitudes, and little attention to performance, output, and efficiency. ( Jain,2004) The term Human Resource Management has been elaborated by William F. Glueckas "that function of all enterprises which provides for effective utilization of people to achieve both the objectives of the enterprise and the satisfaction and development of the employees." (William F. Glueck, 1981)

Administration refers to only recruitment, promotion, transfer, salary and job administration, and industrial relations, whereas Human Resources Management is a subsystem of a larger whole and besides dealing with traditional personnel areas; it deals with human behavior, well-being, and growth at individual and group level. (Ibid) Traditional Personnel management cannot sustain to get better output from the employees in American organizations. HRM is a new and dynamic dimension as a change or development of fundamental environmental instabilities. Traditional concepts, orientations, and power of personnel management functions could not adequately respond. (Wendell L. French)

HRM was recognized as a much broader and softer term in the USA and later on globally. Wendell French, who gave theory, held the view that HRM is the systematic planning, development, and control of a network of interrelated processes affecting and involving all organization members. These processes include Human Resource Planning, Job and Work Designs, Staffing, Training and Development, Performance appraisal and review, Compensation and Reward, Employee Protection and representation, and organizational improvement. To effectively manage these processes, human resources management is planned, developed, and implemented through all managers and human resource specialists' combined efforts along with all employees in the organization. (Ibid)

The HRM as a concept and approach is very vast, broad, and useful. It helps any organization to achieve all objectives and, ultimately, organizational excellence. Paul Pigors and Charles Myers have rightly opened that, "It is through the combined efforts of people that monetary and material resources are utilized for organizational objectives. (Paul Pigors and Charles Myers, 1981).

Byans and Rue have defined HRM as "encompasses those activities that are designed to provide for and coordinate the human resources of an organization. (LlyodL.Byars and Leslie W. Rue, 1984). N.K. Singh looked at a broader view regarding HRM and opined, "HRM refers to the holistic approach to managing people. It has welfare, recruitment and establishment role, potential development in a composite framework of management (N.K. Singh, 2003). In Bangladesh, Government management is inefficient. Monumental mismanagement affects our power sector for the absence of proper management, especially for the lack of appropriate H.R. management. The people of Bangladesh are suffering from a massive power crisis; at this stage, additional power needs to be added to the national grid as soon as possible. So in the electricity sector, skilled and experienced human resources and a robust H.R. system are badly needed to meet the gap between high demand and less supply and ensure effectiveness and efficiency of power generation and distribution

\section{Methodology Of The Study}

The study is conducted in the Electricity sector in Bangladesh. The sctor is chosen to achieve the objectives. Target population refers to the total number of employees from which the study intends to collect data. The targeted respondents are directly related to the Electricity Generation and Distribution Organizations like Engineers, Managers, supervisors, in charge, and other staff. The sample for the study is 30 . The study is made on both primary and secondary sources of data. The primary data is collected through Face-to-Face conversations with the managers, officers, and staff, 
Interviewing managers, officers, and staff, sharing practical knowledge of officials. Secondary data is also collected from the related department's desk report, online data from the Bangladesh Electricity sector website. Annual reports of different years of the organization, unpublished data, and Newspaper articles about the organization, prior research reports, various books, and periodicals related to the Electricity sector. For data analysis, the research has been conducted using qualitative and quantittative methods. In the case of analyzing data, the "Likert Scale" technique has been used. Data show demographic information presented using Microsoft excels and showed percentage, graphical presentation, tables, charts and data is analyzed thrpouh statistical tool..

\section{BACKGROUND OF THE ELECTRICITY SECTOR IN BANGLADESH}

Firstly, Bhawal (Gazipur district) is known to have been the first consumer of electricity in East Bengal. It had an electric generator in the nineteenth century. As a private enterprise, Octavia Steel Company took the overall responsibility of power generation and distribution in Dhaka city and Dhaka, electric light was first established on 7th December 1901. This company's power generation facility was not very large, and power was supplied to only limited areas of Dhaka. "DEVCO" is another company that builds a power station at Paribagh in 1993 and started generation and distribution of electricity on a commercial basis for the ordinary people. After that, the government of East Pakistan took over all private power generation houses and distribution lines in 1957 and launched Power Development Board (PDB) in 1959 as an associate of the East Pakistan Water and Power Development Authority. It had been developed into an independent body in 1972, and the company's headquarter was in Dhaka. It was working as the responsibility to control power plants and distribution networks throughout Bangladesh. (Banglapidia, retrieved from http://banglapedia.search. com.bd/HT/P)

At first Bangladesh Power Development Board (BPDB) generated transmit and distribute power. In 1996, the Bangladesh government developed National Energy Policy and segregated power generation, transmission, and distribution functions into separate services. BPDB distributes power to mainly the urban areas except for the metropolitan city of Dhaka. Dhaka Electric Supply Authority (DESA) is charging the responsibility of distributing power in Dhaka. Later, DESA is criticized due to some controversial issues and corruption. As a result, the government created a new subsidiary named Dhaka Electric Supply Company Ltd. (DESCO). It provided the responsibility of electricity distribution in the Mirpur, Gulshan, Baridhara, and Uttara area of Dhaka. (Banglapidia, retrieved from http://banglapedia.search.com.bd/HT/P_0241.htm)

A well-planned and organized rural electrification plan did not exist till the 1970s. One of our significant earning sources is agriculture, and electicity is essential for power supply effectively. After independence, Bangladesh developed development plans of Bangladesh recognized the necessity of electrifying rural areas. To accelerate economic growth, employment generation, poverty alleviation, and improving the living standard electrifying rural area is an essential component in the development infrastructure. At that time, the Bangladesh government contracted two consulting firms in the USA to carry out a comprehensive feasibility study on rural electrification in Bangladesh.

The firms considered overall related issues in-depth and recommended a sustainable and feasible rural electrification program. The Board is a statutory Government organization with a fundamental duty to execute countrywide rural electrification. To achieve this objective of the rural electrification program, the Board developed Palli Bidyut Samities (PBS) based on Rural Electric Co-operatives' model in the USA. For PBS's praiseworthy performance at present, the rural people are getting the electricity from this PBS, which created new job opportunities and access to electronic media. It plays a significant role also to improve the living standard and lifestyle of rural people. Electricity facilitates the operating of 86,766 irrigation pumps, 62,875 small and cottage industry units, 373,119 commercial setups, and 8,733 other establishments in the rural areas. Rural Electrification Board (REB) attains outstanding success in the electrifying rural area. The main reason for REB's success is the opening of the Performance Target Agreement (PTA), which encouraged agrarian electric societies to get their performances better. (REB history, retrieved from http://www.reb.gov.bd /about_reb.htm)

In Bangladesh, the supply is much lower than the power demand, so the necessity was felt to generate more power. Government-owned power plants are not enough to fulfill the power demand of the people of the country. But, additional generation capacity required massive investment, so the 
government considers mobilizing finance by attracting the private sector in power generation and, more importantly, to increase power supply to lessen the shortage.

Bangladesh Government planned the "Private Sector Power Generation Policy of Bangladesh" and adopted it in 1996. In 1996, the independent power producers (IPP) initiated coming to generate power. REB signed contracts with Independent Power Producers (IPPs) to buy power from them. IPPs entered the power market under the government's condition that they will be run on a build-ownoperate (BOO) basis. REB purchases all the produced power of IPPs. Later, small power producers (SPP) came into the power market to generate power and serve those not electrified. SPPs own generation plant of $9.9 \mathrm{MW}$ to $30 \mathrm{M} . \mathrm{W}$. But some remote areas and isolated islands are still not getting or covering by the national grid because the maintenance of the National Grid and transportation of fuel is costly, challenging, and risky. These areas are being electrifying through new systems like renewable energy. REB has taken programs to use Solar Photovoltaic Systems (Solar P.V.) for producing electricity. For the first time in Bangladesh, BPDB implemented a pilot project of 0.09 MW capacity of the Grid Connected Wind Energy (GCWE). BPDB also developed a Wind Resource Assessment Station (WRAS) in Cox's Bazar. BPDB also implemented an excellent Solar P.V. electrification project in the Chittagong Hill tracts. (Retrieved from http://www.bpdb.gov. $\mathrm{bd} /$ renewables.htm)

\section{HRM Practices Of Electricity Sector (Human Resource Management Practices ON BPDB)}

\subsection{Categories of Staff}

There will be the following categories of staff.

Regular Employees: Employees who are doing the job as stable and permanent and the employee shall remain in employment until either superannuation from the services on the attainment of superannuation age or termination/resignation from services before the triumph of superannuation.

Contract Employees: "Contract Employee" denotes any people with the required knowledge, technical experience, and particular competencies necessary to carry out the duties of the job for a fixed period as restricted within specific terms and conditions laid down in his/her contract. The employment in such cases will terminate on the contract's expiry period unless a further extension of the job.

General Terms and Conditions of Service

All regular employees must be appointed through an appointment order, which must be signed and approved by the respective appropriate Authority. The appointment order must include the following information.

\section{Date of start of services}

Details about Designation and Grade

Full salary includes reference to all issues of pay and deductions thereof.

General guidelines on code of conduct

Probation period

Assessment and confirmation cycle

Bonus and Increment

Place of posting and work timings

Secrecy

Training Needs Assessment

This review of the training and development needs is based upon the following review, data, analysis, and research:

A review of the proposed organizational structure

The staffing plan 
Roles and functions

Review of the various training institutions under BPDB

\subsection{Critical Issues with the Current Training Regime}

Now the following training programs are governed and administered by BPDB:

High Technical Orientation - The programs executed at the different training institutes under PDB has a very high technical orientation. But there is a lacking to improve management skill because all employees are not given opportunities to such training,

Quality of Course Content - There is no existing method to check either the course content's quality or the quality of delivery of the course.

Training a Reward or Privilege - BPDB has considered training as a reward or privilege granted indiscriminately to assert power or position. Staff is frequently sent on training programs where their experience and role have no relevance to the area of training provided. It's a negative issue for the power sector in case of settlement of training.

Knowledge Capture -

When the training has been approved, there has been no coordinated approach to capture that learning by the BPDB. Unless each individual has used his/her initiative to spread the knowledge obtained, the experience gets lost with the participant finishing his/her course. There is no organized system of know-how available to all staff for reference.

Post-Training Application -

When new skills are acquired, there is no clear strategy to make specific training skills experienced and enhanced. In many cases, the staff does not have the opportunity to put training into effect at the local offices either because of being short of proper facilities or lacking initiative.

6. ANALYSIS

\subsection{Demographic Analysis}

\begin{tabular}{|l|l|l|l|l|}
\hline No & Questions & Options & Frequency & Percentage \\
\hline 1 & Sex & Male & 30 & $100 \%$ \\
\hline 2 & Age & Above 45 years & 13 & $43 \%$ \\
\hline 3 & Designation & Other & 20 & $67 \%$ \\
\hline 4 & Length of their relationship & More than 10 Years & 13 & $43 \%$ \\
\hline
\end{tabular}

Source: Survey Result

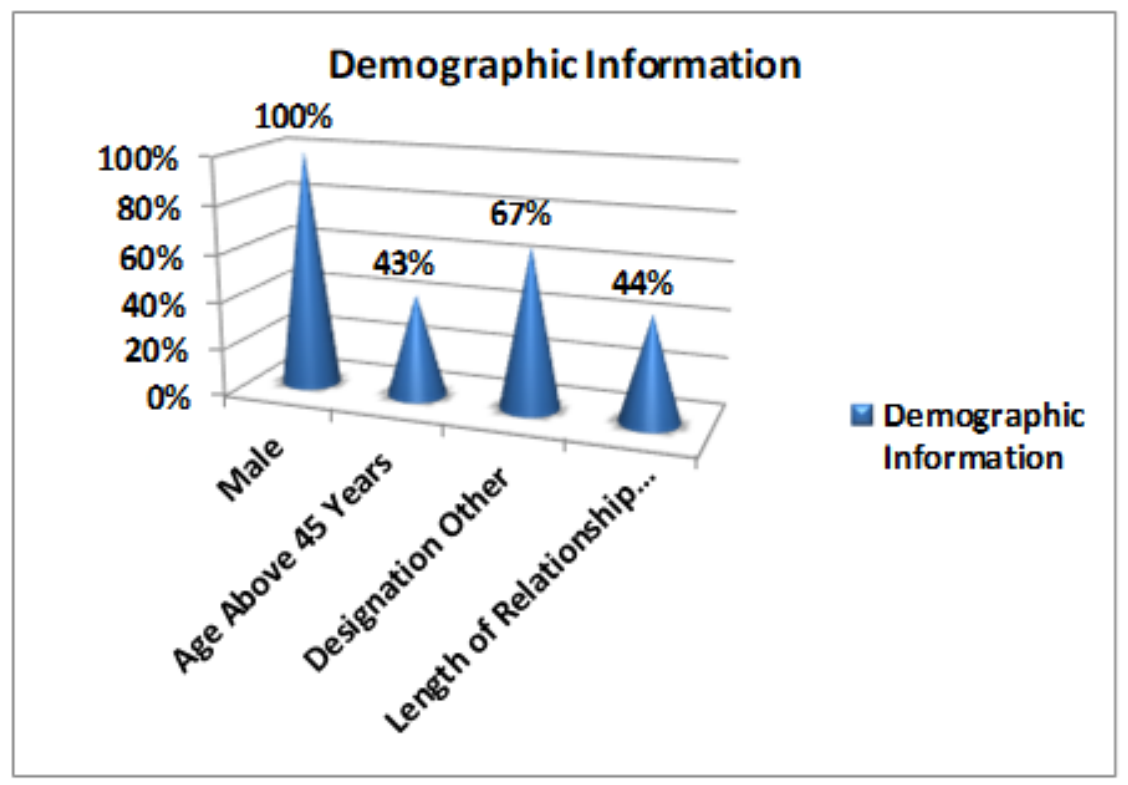

Survey Report

From all the respondents, we can see that $100 \%$ of respondents are male. There is no female respondent. And we can see that the highest $43 \%$ of respondents are in the age group above 45 years 
among the age groups. And the second-highest age group is 25 to 34 years. Most of the respondents are involved in other positions of designation (67\%). But most of them are engineers. It is seen that the majority of the respondents (44\%) have been working for more than ten years. Other respondents are working for 6 to 10 years in the power sector.

\subsection{Questionnaire and Statistical Analysis}

\begin{tabular}{|c|c|c|c|c|c|c|c|}
\hline SL & Criteria/Questionnaire & SD & $\mathrm{D}$ & $\mathrm{N}$ & A & $\mathrm{SA}$ & No. of respondent \\
\hline 1 & $\begin{array}{l}\text { HR management } \\
\text { policies are formalized, } \\
\text { documented and } \\
\text { approved by the } \\
\text { appropriate authority }\end{array}$ & 0 & 0 & 0 & 4 & 26 & 30 \\
\hline 2 & $\begin{array}{l}\text { HR management } \\
\text { policies comply with } \\
\text { employment, } \\
\text { workplace health and } \\
\text { safety, and other } \\
\text { related legislation }\end{array}$ & 0 & 0 & 3 & 11 & 16 & 30 \\
\hline 3 & $\begin{array}{l}\text { HR management } \\
\text { policies are reviewed } \\
\text { on a regular basis and } \\
\text { revised, if necessary }\end{array}$ & 0 & 0 & 4 & 14 & 12 & 30 \\
\hline 4 & 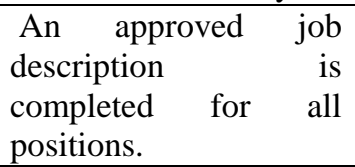 & 0 & 0 & 0 & 12 & 18 & 30 \\
\hline 5 & $\begin{array}{l}\text { Criteria used to select } \\
\text { the appropriate person } \\
\text { are established and } \\
\text { documented. }\end{array}$ & 0 & 0 & 3 & 11 & 16 & 30 \\
\hline 6 & $\begin{array}{l}\text { Selection of candidate } \\
\text { in the organization is } \\
\text { strictly based on his/her } \\
\text { merit }\end{array}$ & 0 & 0 & 0 & 13 & 17 & 30 \\
\hline 7 & $\begin{array}{lr}\text { Managers } & \text { and } \\
\text { supervisors } & \text { are } \\
\text { provided } & \text { with } \\
\text { appropriate } & \text { learning } \\
\text { opportunities } & \text { to } \\
\text { develop } & \text { their } \\
\text { supervisory skills. } & \end{array}$ & 0 & 0 & 4 & 12 & 14 & 30 \\
\hline 8 & $\begin{array}{l}\text { All employees have a } \\
\text { work plan and } \\
\text { performance objectives } \\
\text { that identify the } \\
\text { activities and expected } \\
\text { results for future } \\
\text { performance. }\end{array}$ & 0 & 0 & 7 & 11 & 7 & 30 \\
\hline 9 & $\begin{array}{l}\text { The performance of } \\
\text { each employee is fairly } \\
\text { assessed, at least } \\
\text { annually, at the end of } \\
\text { the work plan or } \\
\text { performance period }\end{array}$ & 0 & 0 & 6 & 13 & 10 & 30 \\
\hline 10 & $\begin{array}{l}\text { Organization appraises } \\
\text { the performance of its } \\
\text { employees at regular } \\
\text { intervals. }\end{array}$ & 0 & 0 & 10 & 12 & 7 & 30 \\
\hline 11 & $\begin{array}{l}\text { Organization's } \\
\text { performance goals are } \\
\text { set at realistic levels }\end{array}$ & 0 & 0 & 6 & 16 & 6 & 30 \\
\hline
\end{tabular}


Human Resource Management (HRM) Practices of the Electricity Sector in Bangladesh

\begin{tabular}{|c|c|c|c|c|c|c|c|}
\hline 12 & $\begin{array}{lr}\text { The } & \text { organization } \\
\text { provides competitive } \\
\text { compensation } \\
\text { employees. }\end{array}$ & 0 & 0 & 8 & 17 & 5 & 30 \\
\hline 13 & $\begin{array}{l}\text { The organization is } \\
\text { committed to providing } \\
\text { a saferr work } \\
\text { environment. }\end{array}$ & 0 & 0 & 3 & 14 & 13 & 30 \\
\hline 14 & $\begin{array}{l}\text { The organization } \\
\text { ensures a work } \\
\text { environment free of } \\
\text { harassment. }\end{array}$ & 0 & 0 & 3 & 6 & 21 & 30 \\
\hline 15 & $\begin{array}{lr}\text { The organization } & \text { is } \\
\text { committed } & \text { to } \\
\text { promoting an inclusive } \\
\text { workplace. }\end{array}$ & 0 & 0 & 3 & 15 & 12 & 30 \\
\hline 16 & $\begin{array}{l}\text { The organization has } \\
\text { established procedures } \\
\text { and informed } \\
\text { employees with regard } \\
\text { to how to resolve } \\
\text { conflicts within the } \\
\text { organization. }\end{array}$ & 0 & 0 & 4 & 22 & 4 & 30 \\
\hline 17 & $\begin{array}{lr}\text { Every } & \text { employee's } \\
\text { training } & \text { and } \\
\text { development needs are } \\
\text { reviewed at least } \\
\text { annually and plans } \\
\text { established to address } \\
\text { any gaps. }\end{array}$ & 0 & 0 & 0 & 23 & 7 & 30 \\
\hline 18 & $\begin{array}{lr}\text { During } & \text { the } \\
\text { development } & \text { of the } \\
\text { annual } & \text { budget, } \\
\text { consideration is given } \\
\text { to } & \text { including } \\
\text { appropriate } & \text { resources } \\
\text { to fund employee } \\
\text { training } \\
\text { development }\end{array}$ & 0 & 0 & 4 & 18 & 8 & 30 \\
\hline 19 & $\begin{array}{l}\text { The contents of the } \\
\text { training programs } \\
\text { organized are always } \\
\text { relevant to the } \\
\text { changing needs of the } \\
\text { jobs and the business. }\end{array}$ & 0 & 0 & 12 & 9 & 9 & 30 \\
\hline 20 & $\begin{array}{l}\text { The organization has a } \\
\text { process to review } \\
\text { staffing needs resulting } \\
\text { in a plan to address } \\
\text { those needs }\end{array}$ & 0 & 0 & 9 & 19 & 2 & 30 \\
\hline 21 & $\begin{array}{l}\text { Critical positions in the } \\
\text { organization are } \\
\text { identified and } \\
\text { succession plans are } \\
\text { established to address } \\
\text { any potential gaps }\end{array}$ & 0 & 0 & 6 & 20 & 4 & 30 \\
\hline 22 & $\begin{array}{l}\text { Pay increments offered } \\
\text { by the organization are } \\
\text { satisfactory }\end{array}$ & 0 & 0 & 6 & 21 & 3 & 30 \\
\hline 23 & $\begin{array}{l}\text { Adequate } \\
\text { growth opportunities } \\
\text { are available in the }\end{array}$ & 0 & 0 & 3 & 18 & 9 & 30 \\
\hline
\end{tabular}




\begin{tabular}{|l|l|l|l|l|l|l|l|}
\hline & $\begin{array}{l}\text { organization for those } \\
\text { who perform well. }\end{array}$ & & & & & & \\
\hline 24 & $\begin{array}{l}\text { In this organization } \\
\text { good performers get } \\
\text { promoted first }\end{array}$ & 0 & 10 & 9 & 5 & 6 & 30 \\
\hline 25 & $\begin{array}{l}\text { Organization cares } \\
\text { about employees' } \\
\text { opinions }\end{array}$ & 6 & 5 & 16 & 3 & 30 \\
\hline
\end{tabular}

SD-Significantly disagree, D-disagree, N-Neutral, A-Agree SA- Significantly agree

\begin{tabular}{|c|c|c|}
\hline Particular & Mean & Variance \\
\hline SD & .00 & .000 \\
\hline D & .64 & 5.240 \\
\hline N & 4.72 & 10.377 \\
\hline A & 14.08 & 25.660 \\
\hline SA & 10.20 & 38.250 \\
\hline Not Agree & 5.36 & 19.323 \\
\hline Agree & 24.28 & 21.710 \\
\hline
\end{tabular}

I have split the Likert scales into two group as not agree $(\mathrm{SD}+\mathrm{D}+\mathrm{N})$ and agree $(\mathrm{A}+\mathrm{SA})$ to explore the satisfactory level of HR management.

\begin{tabular}{|l|l|l|l|}
\hline Satisfaction level & Mean & Standard Error (S.E.) & $95 \%$ confidence interval \\
\hline Not Agree & 5.36 & 0.879 & $(3.55,7.17)$ \\
\hline Agree & 24.28 & 0.932 & $(22.36,26.20)$ \\
\hline
\end{tabular}

Since the mean of agree is about 5 times higher than not agree, so it is clear that the respondents are satisfied with HR management service.

\section{SPECIFIC FINDINGS}

From this Study on Human Resources management practice in the Electricity sector, some significant findings have come out.

- There is a robust H.R. management system that is followed and practiced in the Electricity sector.

- H.R. management policies are followed sincerely.

- A fair recruitment process is practiced.

- Different training programs are organized for different types of the workforce throughout the year.

- The promotion process is not transparent.

- There are some conflicts between trade union and companies.

- There is energetic workforce in this sector.

- An approved job description is completed for all positions.

- The performance of each employee is fairly assessed.

- Companies are maintaining a safe working environment for their employees and workers.

- Training and Development programs are arranged regularly.

- Pay increments offered by the organization are less satisfactory.

8. RECOMMENDATION

The following recommendation should be considered for the improvement of the power sector in Bangladesh.

- The power sector should ensure that a standard HRM policy achieves an improvement in Electricity generation and distribution. It will accelerate the overall H.R. management improvement that leads to improved organizational operational and financial performance.

- A proper Human Resource Management System is likely to improve. It reduced absenteeism, improved employee commitment, and adequate information flow and made it easier for the organization to meet its goals. 
- The government should introduce more Professional Training Programs for the employees.

- New Technologies are introducing now, and training for adopting new technology is badly needed for the power sector personnel.

- A transparent and fair promotion should be followed in the power sector. Increments, bonuses, and other financial incentives should be paid regularly. Besides this, other influential activities should be practiced by the power-related organization to motivate its' personnel.

\section{CONCLUSION}

The need for electricity in Bangladesh cannot be expressed in words; the effect of power in every growing sector of Bangladesh is undeniable. The economic goals of the country cannot be achieved without flourishing the power sector of Bangladesh. At present, it is way over time that we are still locating the gaps and shortfalls in the power sector, now it is time to act. However, the government holds the key to this sector. The private sector should always be encouraged to participate in the power sector to accomplish the government's plan for the power sector. A standard HRM policy should be implemented as soon as possible to make the power sector effective. Fair recruitment, training, and promotion practices significantly contribute to the efficiency of the Electricity Sector. Training and Development programs ensure the highest efficiency in electricity generation and distribution. Therefore, it would be essential if Electricity generation and distribution organizations earnestly implement a human resource management system. So in the electricity sector, skilled and experienced human resources and a healthy H.R. system are badly needed to meet the gap between high demand and less supply and ensure effectiveness and efficiency of power generation and distribution service.

\section{ACKNOWLEDGMENT}

I thank them because I use their findings in the paper for the review of the literature. Brill and Konar, Rousseau, Akio Morita, J. Phillip, Dessler, Jain, William F. Glueck, Wendell L. French, Paul Pigors and Charles Myer, Llyod L. Byars and Leslie W. Rue, and N.K. Singh.

I also acknowledge the Research and Development division of Jatiya Kabi Kazi Nazrul Islam University, Mymensingh, Bangladesh. This division will give me the funding for the paper publication.

\section{REFERENCES}

[1] Akio Morita,Made in Japan, E.P. Dutton, New York, 1986, p. 130.

[2] Lumayo f. Mildred, an assessment of the effects of computerized human resource information systems on employee performance: a case of the deputy county commissioners, 2014, p.01

[3] Dessler, G. (2005) Human Resource Management, 10.ed, USA: Prentice Hall.

[4] Rousseau, D. M. (2004). Psychological contracts in the workplace: Understanding ties that motivate. Academy of Management Executive, 18: 120-127.

[5] J. Phillip in Valedictory Address at the Seminar on Human Value and Organizational RensisLikert, the Human Organization-Its Management and Value, McGraw Hill, NewYork, 1967, p. 1.

[6] N.C. Jain, Dictionary of Management, AITBS Publishers and Distributors, New Delhi, 2004, p.171.

[7] William F. Glueck, Management, Dryden Press, Illionois, 1981, p. 669.

[8] Wendell L.French, Human Resource Management, All India Publishers and Distributors ,Chennai,p. 4.

[9] Ibid. p. 6.

[10] Paul Pigors and Charles Myers, Personnel Administration, McGraw Hill, Mumbai, 1981, p. 6.

[11] Llyod L. Byars and Leslie W. Rue, Human Resource and Personnel Management, Richard \& Irwin, Homewood, Illinois, 1984, p. 7.

[12] N.K. Singh, Human Resource Management, Excel Books, New Delhi, 2003, p.4.

[13] Government of Bangladesh / ADB ADB TA 4626-BAN: Corporatization of Bangladesh Power Development Board Final Report - Main Document 21 July 2008

[14] http://banglapedia.search.com.bd/HT/P)

[15] http://banglapedia.search.com.bd/HT/P_0241.htm)

[16] http://www.reb.gov.bd/about_reb.htm

[17] http://www.bpdb.gov.bd/renewables.htm) 
[18] (https://en.m.wikipedin.org/wiki/Electricity_Sector_in_Bangladesh)

[19] "Nuclear Power in Bangladesh". world-nuclear.org. Retrieved 8 June 2017.

[20] "Booming Energy Sector Of Bangladesh: 90 Percent Have Access To The Electricity". bdnewsnet.com. Dhaka,Bangladesh. Bangladesh News Network. 12 July 2018. Retrieved 17 July 2018. http://www.bpdb. gov.bd/bpdb/index.php?option=com_content\&view=article\&id=150\&Itemid=16

[21] "Key Statistics". Bangladesh Power Development Board. Retrieved 3 November 2014.

[22] "In pictures: Celebrating 20,000MW of power". Dhaka Tribune. 8 September 2018. Retrieved 4 January 2019.

[23] Jump up to:a b Rashid and Sajjad (20 August 2018). "Powering the nation". Dhaka Tribune. Retrieved 4 January 2019.

[24] "Source of Light in Bangladesh : 2015". Archived from the original on 15 August 2017. Retrieved 8 June 2017.

[25] "Govt plans to sign energy pact with Bangladesh". The Himalayan Times. 16 April 2018. Retrieved 9 May 2018.

[26] "Nasrul: Lack in electricity management caused blackout - Dhaka Tribune". dhakatribune.com. Retrieved 21 September 2015.

[27] Jump up to:a b "Nationwide blackout in Bangladesh ends - LA Times". Los Angeles Times. 2 November 2014. Retrieved 3 November 2014.

[28] Philip M. Rosenzweig \& Nitin Nohria (1994) Influences on Human Resource Management Practices in Multinational Corporations, Journal of International Business Studies volume 25, pages 229-251(1994)

[29] Mohan Pyari Maharjan \& Tomoki Sekiguchi (2016.) Human resource management practices at foreignaffiliated companies in least-developed regions: US and Japanese Companies in Nepal, Asian Business \& Management volume 15, pages137-164(2016)

[30] Sabine Raeder(2019) The role of human resource management practices in managing organizational change, Gruppe. Interaktion. Organisation. Zeitschrift für Angewandte Organisationspsychologie (GIO) volume 50, pages169-191(2019)

[31] Fiza Amjad, ,et.all,(2021) Effect of green human resource management practices on organizational sustainability: the mediating role of environmental and employee performance, Environmental Science and Pollution Research (2021)

\section{AUTHOR'S BIOGRAPHY}

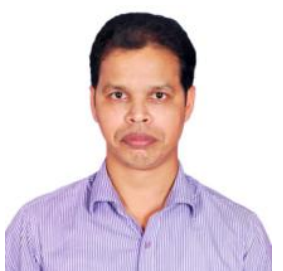

Md. Shafiqul Islam, is known as Shafiq Shahin. I have been teaching at the Jatiya Kabi Kazi Nazrul Islam University for about 9 years. He is a teacher in the Department of Accounting and Information Systems. I am working as an Assistant professor in the said department. I am writing in various English and Bengali newspapers and magazines. I have 10 academic articles in local and foreign journals. I achieved gold medal winning student at the undergraduate and postgraduate levels. I was the General secretary and President of the Teachers' Association at my university for the last three years. About 120 of my articles have been published in leading newspapers in Bangladesh. I am currently doing research as a PhD Fellow at Zhongnan University of Economics and Law in Wuhan, China. I have given the lecture on Principles of Finance, Strategic Management, Business ethics and corporate governance, International Financial Management and Advanced Accounting etc.

Citation: Md. Shafiqul Islam, “ Human Resource Management (HRM) Practices of the Electricity Sector in Bangladesh" International Journal of Managerial Studies and Research (IJMSR), vol 9, no. 5, 2021, pp. 01-11. doi: https://doi.org/10.20431/2349-0349.0905001.

Copyright: (C) 2021 Authors. This is an open-access article distributed under the terms of the Creative Commons Attribution License, which permits unrestricted use, distribution, and reproduction in any medium, provided the original author and source are credited. 